\title{
Karakterisasi Bakteri Penambat N Asal Bayam Liar (Amaranthus spinosus L.) Sebagai Pemacu Perkecambahan Benih Bayam Hijau (Amaranthus spp. L.)
}

\section{(Characterization of N-fixing Bacteria Isolated from Wild Spinach (Amaranthus spinosus L.) as Stimulation for Green Spinach (Amaranthus spp. L.) Seed Germination)}

\author{
$\underline{\text { Mutiara }}^{1}$, Fadjar Rianto $^{*^{2}}$, Wasian $^{2}$ \\ ${ }^{1}$ Prodi Magister Agroteknologi Fak. Pertanian \\ ${ }^{{ }_{2},}$ Jurusan Budidaya Pertanian Fakultas Pertanian Universitas Tanjungpura Jl. Prof Hadari Nawawi Pontianak 78124 email: \\ fajar.rianto@faperta.untan.ac.id
}

Diterima 21 Desember 2016/Disetujui 14 Januari 2017

\begin{abstract}
ABSTRAK
Spinach required relatively high Nitrogen to grow it in less fertile fields. The use of free living $N$-fixing bacteria were expected to facilitate $N$ supply to the crop. The research aims was to characterized of $N$-fixing bacterial isolates and its role to spinach germination. The exploration of bacterial isolates, were collected from wild spinach roots using LG and Ashby media. Bacterial isolates which were obtained, then being characterized based on its ability to dissolve $P$ and produced indole compounds in Picovskaya and TSB media respectively, enriched with tryptophan. Superior isolates were used in the spinach germination test. Germination test using the UDK method in merang paper. The variables measured in this study were normal seedling, seedling vigor, root length, and height of normal seedling. The isolation results obtained 16 isolates that can fix $N, 3$ isolates (12BH3, 13BH4 and 1BH4) were higher in dissolving $P$ and capable to produce indole compounds. Isolates 12BH3, $13 B H 3$ and commercial isolates were used in the germination test. Test result showed that the bacteria can increase the $N$ fixation, and high normal seedling sprouts.
\end{abstract}

Keywords: germination test, $P$ solvent, $N$-fixing bacteria, spinach

\section{ABSTRACT}

Kebutuhan hara $N$ pada bayam cukup tinggi, terutama jika ingin mengembangkannya di lahan yang kurang subur. Penggunaan bakteri penambat $N$ yang hidup bebas diharapkan dapat membantu penyediaan $N$ untuk tanaman. Penelitian bertujuan untuk melakukan karakterisasi isolat bakteri penambat $N$ dan melihat peranannya dalam perkecambahan bayam cabut. Eksplorasi isolat bakteri dilakukan dari perakaran bayam liar menggunakan media LG dan Ashby. Isolat bakteri yang diperoleh dikarakterisasi berdarkan kemampuan melarutkan P dan menghasilkan senyawa indol, masing-masing pada media Picovskaya dan TSB yang diberi triptofan. Isolat yang unggul digunakan dalam uji perkecambahan bayam. Uji kecambah menggunakan metoda UDK pada kertas merang. Variabel yang diamati kecambah normal, vigor kecambah, panjang akar dan tinggi kecambah normal. Hasil isolasi diperoleh 16 isolat bakteri yang dapat menambat $N$, 3 isolat (12BH3, 13BH4 dan 1BH4) diantaranya unggul dalam melarutkan $P$ dan dapat memproduksi senyawa indol. Pada pengujian daya kecambah digunakan isolat 12BH3, $13 \mathrm{BH} 3$ dan isolat komersial. Pengujian menunjukan bahwa isolat bakteri penambat $N$ dapat meningkatkan kecambah normal dan tinggi kecambah.

Keywords: bayam, bakteri penambat $N$, pelarut $P$, uji kecambah

\section{PENDAHULUAN}

Bayam (Amaranthus sp) merupakan sayuran yang berasal dari daerah Amerika Tropik. Bayam awalnya dikenal sebagai tanaman hias, namun dalam perkembangannya bayam lebih dikenal dan dipromosikan sebagai bahan pangan sumber protein, vitamin $\mathrm{A}$ dan $\mathrm{C}$ serta sedikit mengandung vitamin $\mathrm{A}$ dan $\mathrm{C}$ yang mengandung garam garam mineral seperti kalsium, pospor dan zat besi (Sunarjono, 2006).
Bayam mempunyai peran yang penting dalam memperbaiki gizi masyarakat. Pada bayam selain dapat memperlancar pencernaan juga banyak mengandung vitamin A, vitamin C serta banyak mengandung garam- garam mineral yang penting (kalsium, fosfor, besi) untuk mendorong pertumbuhan dan menjaga kesehatan. Anjuran konsumsi sayuran Indonesia untuk mencapai sehat gizi adalah $65,5 \mathrm{~kg} / \mathrm{kapita} / \mathrm{tahun}$. Konsumsi sayuran sehat gizi di Indonesia baru terpenuhi 80\% (Rukmana, 1994). Cukup banyak pasokan yang harus dipenuhi untuk mencukupi 
kebutuhan sayuran masyarakat. Tidak semua wilayah di Indonesia dapat dijadikan areal tanaman sayur.

Wilayah pengembangan untuk sayuran umumnya dilakukan pada lahan-lahan tergolong subur sehingga jika ingin dikembangkan di lahan kering akan banyak menghadapi kendala. Untuk menanam bayam dianjurkan menggunakan pupuk kotoran ayam 40 ton/ha dan juga urea $150 \mathrm{~kg} / \mathrm{ha}$ sebagai stater (Edi dan Bobihoe, 2010). Peningkatan produksi sayuran bisa juga diharapkan melalui penggunaan pupuk hayati. Sawi daging yang diberi pupuk hayati $45 \mathrm{~kg} /$ ha ternyata dapat meningkatkan tinggi, jumlah daun, serta lebar tajuk. Selain itu pupuk hayati yang digunakan juga dapat menekan serangan akar gada 70,83\% (Rahmawati dan Korlina, 2016).

Bayam mempunyai kemampuan adaptasi yang tinggi pada berbagai lingkungan habitat tumbuhnya sehingga masih bisa tumbuh pada lahan suboptimal sekalipun. Biasanya bayam-bayam liarlah yang mampu beradaptasi dengan lahan suboptimal, dan jenis ini kurang digemari sebagai sayuran. Kemampuan tumbuh vegetatif yang baik dimungkinkan terjadi karena ada peran mikroba yang berasosiasi di rizosfir, diantaranya adalah bakteri penambat $\mathrm{N}$ yang hidup bebas.

Bakteri penambat $\mathrm{N}$ seperti Azotobacter mempunyai peran dalam membantu pertumbuhan tanaman. Bakteri yang diisolasi dari rizosfir padi, sebanyak 21 isolat mampu tumbuh pada media bebas $\mathrm{N}$, menghasilkan senyawa indole dan melarutkan $\mathrm{P}$ yang terikat $\mathrm{Ca}$ (Nurmas et al., 2014). Penggunaan bakteri menyerupai Azotobacter atau Azospirillum dan konsorsiumnya dapat meningkatkan jumlah gabah per malai, bobot gabah per petak, serapan $\mathrm{N}$ dan mengurangi $25 \%$ dari dosis $\mathrm{N}$ anjuran pada tanaman padi (Widiyawati et al., 2014). Peningkatan pertumbuhan oleh 7 isolat bakteri penambat $\mathrm{N}$ yang diantaranya Azotobacter akan lebih jika diimbangi dengan pemakaian bahan organik yang digunakan sebagai pupuk (Aryanto et al., 2015). Genus Azotobacter dapat mensintesa auksin, sitokinin, dan sejenis GA yang kesemuanya dapat meningkatkan pertumbuhan. Hormon tumbuh ini akan dilepaskan di rizosfir atau permukaan akar sehingga beriukutnya mempengaruhi pertumbuhan tanaman. Untuk memastikan efektivitas inokulan bakteri perlu diperhatikan kompatibilitas antara tanaman dengan strain Azotobacter sehingga dapat terbentuk asosiasi yang baik (Wani, 2013).

Penelitian bertujuan untuk melakukan karakterisasi isolat bakteri penambat $\mathrm{N}$ hidup bebas asal bayam liar dan pengujian kemampuannya dalam meningkatkan perkecambahan bayam cabut. Isolat bakteri yang diperoleh diharapkan dapat dikembangkan sebagai upaya mengatasi ketidak sesuaian lahan suboptimal dalam mengembangkan tanaman bayam.

\section{METODOLOGI}

Eksplorasi bakteri penambat $\mathrm{N}$ dilakukan dari rizosfer bayam liar yang tumbuh subur di lahan PMK. Isolasi bakteri penambat $\mathrm{N}$ menggunakan metoda tuangpengenceran (Hastuti, 2012).

\section{A. Isolasi bakteri Penambat $\mathbf{N}$}

Isolasi bakteri penambat $\mathrm{N}$ dilakukan dari beberapa rizosfir bayam liar yang mengelompok tumbuh di tanah PMK desa Bani Amas Kecamatan Bengkayang Kalbar.Tanaman yang dipilih memperlihatkan pertumbuhan yang subur dan hidup normal. Sebanyak $100 \mathrm{~g}$ campuran tanah dan akar dari rizosfer ditambahkan $500 \mathrm{ml}$ akuades steril dalam gelas piala dan dikocok selama 3 menit. Pengenceran dilakukan sampai $10^{-3}$, dan sebanyak $100 \mu \mathrm{l}$ dari masing-masing pengenceran dituang dan disebarkan dalam petri yang berisi media LG. Inkubasi dilakukan pada suhu kamar selama 7-10 hari.

\section{B. Karakterisasi Bakteri Penambat N Bebas}

Koloni bakteri yang tumbuh pada media LG direisolasi pada media Ashby untuk memastikan bahwa isolat yang diisolasi mirip dengan Azotobacter. Koloni isolat bakteri berwarna putih kotor atau krem, mengkilat, convek, bertekstur halus dimurnikan untuk dilakukan karakterisasi. Karakterisasi berdasarkan kemampuan sebagai pelarut $\mathrm{P}$ (Ca-P) dan menghasilkan senyawa indol.

\section{- Kemampuan Sebagai Pelarut P}

Uji kemampuan melarutkan $\mathrm{P}$ menggunakan media Pikovskaya (10 g glukosa; 0,5 g $\left(\mathrm{NH}_{4}\right)_{2} \mathrm{SO}_{4} ; 7,69 \mathrm{~g} \mathrm{Fe}_{3} \mathrm{PO}_{3}$; 0,1 g $\mathrm{MgSO}_{4} \cdot 7 \mathrm{H}_{2} \mathrm{O} ; \quad 0,002 \mathrm{~g} \quad \mathrm{MnSO}_{4} \cdot \mathrm{H}_{2} \mathrm{O} ; 0,002 \mathrm{~g}$ $\mathrm{FeSO}_{4} .7 \mathrm{H}_{2} \mathrm{O} ; 0,5 \mathrm{~g}$ yeast ekstrak; $20 \mathrm{~g}$ agar; $1000 \mathrm{ml}$ akuades). Sumber $\mathrm{P}$ yang digunakan terikat $\mathrm{Ca}$, (Santosa, 2012). Semua isolat bakteri yang berindikasi mampu menambat $\mathrm{N}$ ditumbuhkan pada media Pikovskaya. Inkubasi dilakukan pada suhu kamar selama 5 hari. Kemampuan melarutkan $\mathrm{P}$ di tandai dengan terbentuknya zona bening disekitar koloni. Indek kemampuan melarutkan $\mathrm{P}$ dengan mengukur zona bening menggunakan rumus $=\frac{\mathrm{a}-\mathrm{b}}{\mathrm{a}} \times 100 \%$, $\mathrm{a}=$ diameter zona bening; $\mathrm{b}=$ diameter koloni bakteri

\section{- Kemampuan Produksi Senyawa Indole}

Kemampuan menghasilkan senyawa indole dilakukan dengan menumbuhkan isolat bakteri pada media TSB (Trypton Soya Broth) yang ditambahkan L-trypthofan 0,1\%. Inkubasi dilakukan dalam ruang gelap selama 48 jam pada suhu ruang. Selama inkubasi biakan bakteri di kocok pada kecepatan $100 \mathrm{rpm}$. Deteksi produksi senyawa indol dilakukan dengan meneteskan larutan Kovack pada kultur bakteri. Indikasi pembentukan indol ditandai dengan terbentuk lapisan warna merah pada permukaan, semakin pekat warnanya menandakan semakin banyak pula senyawa IAA yang dihasilkan.

\section{- Uji Hipersensitivitas (HR) Isolat Bakteri}

Isolat-isolat bakteri yang yang unggul (dapat menjerap $\mathrm{N}$, melarutkan $\mathrm{P}$, dan produksi senyawa indol) digunakan untuk uji HR pada tembakau. Pengujian dilakukan dengan menginjeksikan kultur cair bakteri 
berumur 48 jam pada jaringan daun (mesofil). Sebelumnya tembakau di inkubasi pada kondisi lingkungan teduh selama 24 jam sebelum diinjeksi dengan kultur cair bakteri. Sebagai kontrol agar terjadi nekrotik digunakan juga kultur cair bakteri patogen. Penilaian nekrotik pada daun ditentukan pada 24 setelah injeksi (Nawangsih, 2007)

\section{Induksi Perkecambahan Bayam}

Beberapa isolat bakteri terpilih (memperlihatkan kemampuan menjerap $\mathrm{N}$, melarutkan $\mathrm{P}$, dan memproduksi senyawa indol) digunakan dalam uji bio-assay terhadap perkecambahan benih bayam varietas Puspita 1. Pengujian perkecambahan menggunakan metoda uji viabilitas pada media kertas merang (Suwarno dan Hapsari, 2008) yang dihamparkan di atas kertas (UDK) dalam wadah kotak plastik mika ukuran $24 \times 24 \times 8 \mathrm{~cm}$. Isolat bakteri yang diujikan adalah $12 \mathrm{BH}_{3}, 13 \mathrm{BH}_{4}$ dan isolat komersial (dijual di pasar).

Benih bayam yang akan diuji sebelumnya direndam selama 12 jam dalam suspensi bakteri (konsentrasi $10^{9} \mathrm{ml}^{-1}$ ) dari masing-masing isolat Pada perlakuan kontrol benih hanya direndam dalam TSB.

Pada pengujian viabilitas benih menggunakan rancangan acak lengkap. Perlakuan meliputi jenis isolat bakteri, dan masing-masing isolat menggunakan 5 ulangan. Setiap ulangan terdiri dari 50 benih bayam yang ditaburkan secara teratur pada permukaan kertas merang yang sudah dilembabkan terlebih dahulu. Pengamatan yang dilakukan meliputi kecambah normal, kecepatan tumbuh, vigor kecambah, panjang akar dan tinggi tanaman. Pengamatan dilakukan pada 3, 4 dan 5 hst, dan untuk pengukuran panjang akar dan tinggi tanaman dilakukan pada 10 hst terhadap 10 kecambah normal yang dipilih secara acak.

Penentuan vigor kecambah ditentukan pada 3 hst menggunakan rumus

\section{$\%$ vigor kecambah $=\begin{aligned} & \sum \text { benih yg tumbuh } \\ & \sum \text { benih yg digunakan }\end{aligned} \quad \mathrm{X} \mathrm{100 \%}$}

kecambah normal ditentukan pada 5 hst menggunakan rumus

$\begin{array}{ll}\% \text { kecambah normal } & \begin{array}{l}\Sigma \text { benih yg tumbuh } \\ \text { normal } \\ =\end{array} \\ & \Sigma \text { benih yg digunakan }\end{array}$

Kecepatan tumbuh ditentukan mulai hari ke 3, 4, 5 hst terhadap benih normal menggunakan rumus:

Kecepatan tumbuh $=\quad \begin{array}{ll}\sum\left(\mathrm{n}_{\mathrm{i}} \mathrm{X} \mathrm{v} \mathrm{v}_{\mathrm{i}}\right) & \mathrm{X} 100 \%\end{array}$

$\mathrm{n}_{\mathrm{i}}=$ jumlah kecambah pada hari ke $\mathrm{i}, \mathrm{v}_{\mathrm{i}}=$ hari saat menjadi kecambah, $\mathrm{N}=$ total benih yang digunakan.

\section{Analisis Data}

Data perkecambahan dianalisis keragamannya dengan menggunakan program Minitab 16. Jika terdapat faktor yang berpengaruh maka akan dilanjutkan dengan nilai uji Tukey. Data hasil karakterisasi isolat-isolat bakteri dilakukan dengan cara tabulasi.

\section{HASIL DAN PEMBAHASAN}

\section{Eplorasi dan Karakterisasi}

Hasil eksplorasi bakteri penambat $\mathrm{N}$ yang hidup bebas dari rizosfer tanaman bayam liar berhasil mendapatkan 14 isolat. Setelah ditumbuhkan pada media Ashby semua isolat memperlihatkan bentuk bundar sampai tidak beraturan, berwarna putih kotor atau krem, diameter koloni berkisar antara 3-5 mm, bertekstur halus dan bekilat seperti tetesan air. Koloni bakteri tersebut mirip seperti yang didapatkan oleh Jiménez et al. (2011). Pada media LG bakteri yang berhasil diisolasi dari rizosfir sayur-sayuran memperlihatkan koloni keputihan, licin, bentuknya tidak beraturan, berkilat berdiameter 3-8 mm. Disamping itu juga diperoleh koloni yang lebih kecil 2-5 mm, transparan, seperti titik air (gambar 1)

Bakteri-bakteri tersebut diperoleh dari bayam yang tumbuh di lahan miskin hara dan kandungan bahan organik yang rendah. Asosiasi antara sebagian besar bakteri dan perakaran tanaman ini diduga mempengaruhi pertumbuhan bayam liar sehingga dapat tumbuh subur pada lahan suboptimal. Ketersediaan unsur N, P dan beberapa unsur makro lainnya sangat penting dalam menunjang pertumbuhan tanaman. Bakteri rizosfer yang berpotensi memfiksasi N, sangat penting dilakukan yang dapat berperan sebagai biofertilizer,agen biokontrol, yang ramah lingkungan dan dapat dikemas sebagai pupuk hayati

Hasil isolasi yang dilakukan oleh Rubio et al. (2013) ada tiga spesies Azotobacter (A. chroococcum, A. salinestris, dan A. armeniacus) yang diisolasi dari lahan pertanian dan non pertanian di Argentina yang sangat potensial dikembangkan sebagai pupuk hayati setelah dilakukan seleksi. Pemilihan didasarkan pada kemampuan biosintesis fitohormon (IAA, GA3 dan Z), aktivitas nitrogenase, produksi siderofor dan pelarutan P. Masing-masing isolat menunjukan kemampuan yang bervariasi. Fitohormon yang dihasilkan pada media berkisar: $2,2-18,2 \mu \mathrm{g}^{\mathrm{IAA}} \mathrm{mL}^{-1}, 0,3-$ $0,7 \mu \mathrm{g}$ GA3 $\mathrm{mL}^{-1}$, dan $0,5-1,2 \mu \mathrm{g} \mathrm{Z} \mathrm{mL}{ }^{-1}$. Tetapi semua isolat yang diperoleh ternyata tidak mempunyai kemampuan melarutkan P.

Keempat belas isolat bakteri yang mampu tumbuh pada media bebas $\mathrm{N}$ diuji kemampuan melarutkan $\mathrm{P}$ dan memproduksi senyawa indol. Semua isolat tersebut memperlihatkan ciri sebagai Azotobacter spp. Hal ini berdasarkan kemampuan tumbuh pada media selektif (tidak mengandung $\mathrm{N}$ ) dan ciri morfologi koloni yang diperlihatkan seperti yang dilakukan oleh Naz et al. (2012) dan Jimenez et al. (2011).. Hasil pengujian (tabel 2) menunjukkan bahwa, tidak semua isolat mampu melarutkan $\mathrm{P}$ dan juga dapat memproduksi senyawa indol. Isolat bakteri yang memiliki kemampuan terbaik melarutkan $\mathrm{P}$ adalah isolat 13BH4, sedangkan isolat bakteri yang bisa memproduksi senyawa indol adalah isolat $12 \mathrm{BH} 3$. Pembentukan indol ditandai oleh terbentuknya cincin warna 
merah pada permukaan kultur bakteri setelah di beri pereaksi Kovacks. Ketidak mampuan isolat Azotobacter dalam menghasilkan senyawa IAA yang sama baiknya juga diperlihatkan pada penelitian Kholaida dan Zulaika (2015), dari 10 isolat yang diuji ternyata hanya 6 isolat yang terindikasi dapat membentuk IAA. Bakteri pemfiksasi nitrogen non simbiosis bisa menghasilkan senyawa fitohormon asam asetat indol (IAA) dan hormon sitokinin yang dapat memacu pertumbuhan akar dan tajuk (Zinniel et al., 2002). Kejadian ini memungkinkan untuk menggunakan isolat $12 \mathrm{BH} 3$ dan $13 \mathrm{BH} 4$ dalam memacu perkecambahan benih bayam.

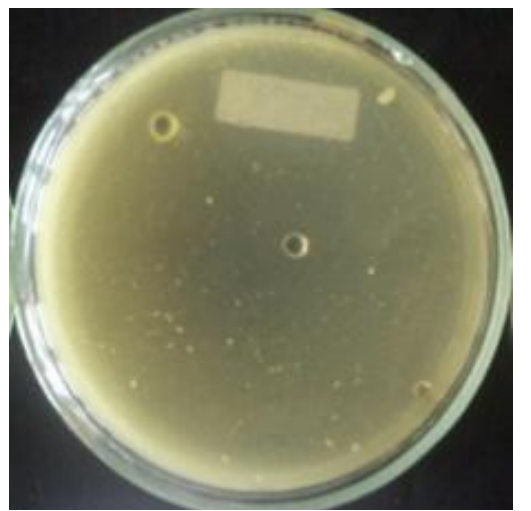

Gambar 1. Isolat Bakteri Rizosfer inkubasi 5 hari, suhu ruang, pada Media LG

Penambahan triptofan pada media akan memicu bakteri untuk lebih banyak membentuk senyawa indol. Pada media cair kultur $A$. vinelandii yang diberi $0,1 \mathrm{mg} \mathrm{ml}^{-1}$ bisa meningkatkan fitohormon IAA yang berbeda dibandingan jika media tersebut tidak diberi triptofan Terjadi peningkatan produksi IAA dari $0,9 \mu \mathrm{g} \mathrm{ml}^{-1}$ menjadi $2,7 \mu \mathrm{g} \mathrm{ml}^{-1}$ (Naz et al., 2012). Tryptofan adalah asam amino yang menjadi prekursor dalam metabolisme pembentukan senyawa indol. Senyawa indol merupakan prekursor penting yang dibutuhkan oleh tanaman dalam memproduksi senyawa IAA yang dibutuhkan tanaman. Pembentukan IAA yang masuk dalam bentuk senyawa indol tersebut sejalan dengan jumlah tryptofan yang diserap oleh Pythium ultimum (Rey et al., 2001). Meningkatnya sintesa IAA dipengaruhi oleh triptofan yang diberikan dalam media tumbuh Enterobacter dan Klebsiella (Mirza et al., 2001).

Kemampuan bakteri melarutkan $\mathrm{P}$ yang terikat $\mathrm{Ca}$ ternyata tidak dimiliki oleh semua isolat bakteri yang mampu menjerap N. Hasil penelitian menunjukan dari 16 isolat yang diujikan ada 4 isolat yang memiliki kemampuan melarutkan P. Mekanisme pelarutan posfat berhubungan dengan kemampuan bakteri dalam menghasilkan asam organik seperti asam asetat, asam oksalat, suksinat dan ketoglutarat (Ilmer dan Schinner 1995) ataupun menghasilkan fosfatase. Pengukuran persentase bakteri dalam melarutkan $\mathrm{P}$ dilihat dari ukuran zona bening yang dihasilkan. Isolat 13BH4 memiliki kemampuan pelarutan $\mathrm{P}$ terbaik pada media Pikovskaya dengan indeks zona bening $80 \%$ (Gambar 2).

Hasil karakterisasi terhadap isolat bakteri yang mampu menjerap $\mathrm{N}$ diperoleh 2 isolat menunjukkan kemampuan melarutkan Ca-P, dan menghasilkan - senyawa indol. Isolat potensial tersebu adalah $12 \mathrm{BH}_{3}$ dan $13 \mathrm{BH}_{4}$. Hasil pengujian HR dari kedua isolat juga mengindikasikan tidak sebagai patogen terhadap tanaman (gambar 3).

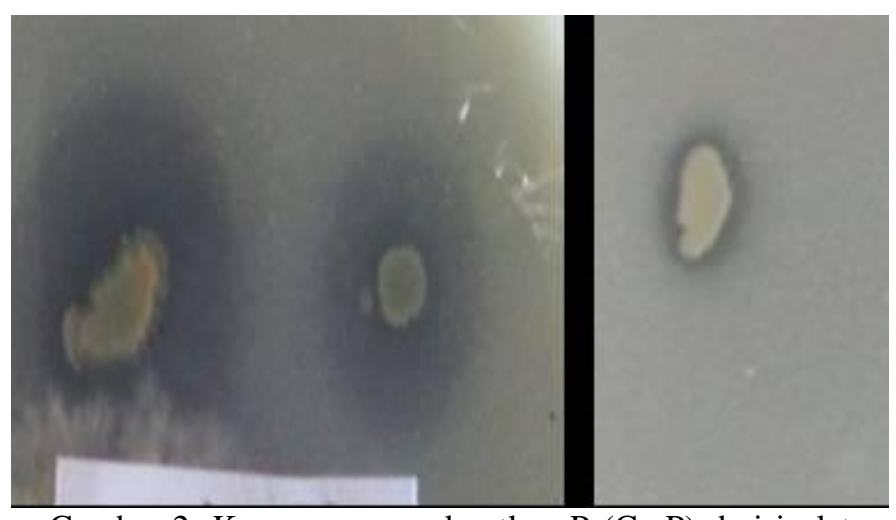

Gambar 2. Kemampuan melarutkan $\mathrm{P}(\mathrm{Ca}-\mathrm{P})$ dari isolat 13BH4

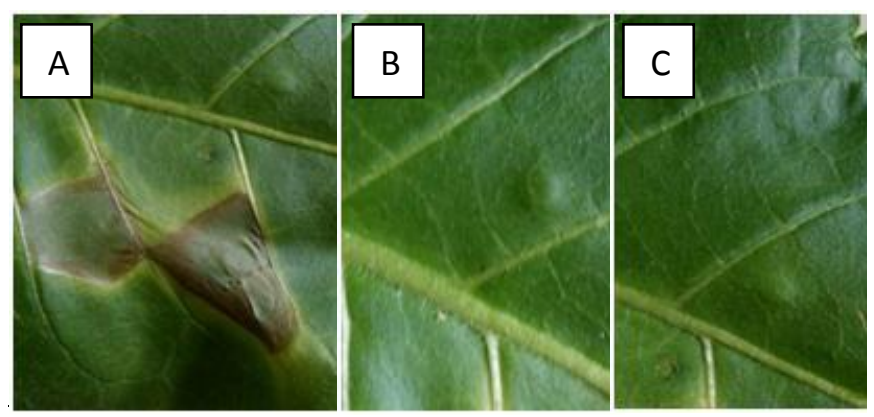

Gambar 4. Hasil uji HR isolat bakteri. A. Isolat bakteri patogen; $\mathrm{B}$, isolat $12 \mathrm{BH} 3 \mathrm{C}$, isolat $13 \mathrm{BH} 4$

\section{Uji Bioassay Perkecambahan Bayam Hijau}

Uji bioassay dilakukan menggunakan benih bayam hijau, yang direndam dalam suspensi 2 isolat bakteri penambat $\mathrm{N}, 12 \mathrm{BH} 3$ dan 13BH4 yang mirip sebagai Azotobacter serta isolat Azotobacter komersial (N2). Pengaruh penggunaan bakteri penambat $\mathrm{N}$ hanya terjadi pada vigor kecambah, kecambah normal dan tinggi tanaman. Benih mentimun yang direndam suspensi $A$. vinelandii dapat meningkatkan kemampuan berkecambah dan pertumbuhan kecambah 16,4 dan $1,9 \%$, serta panjang kecambah $11,8 \%$ dibandingkan kontrol yang hanya direndam dalam air. Reaksi peningkatan perkecambahan besarannya tidak sama antar jenis benih seperti tomat, kubis merah dan bit (Kurdish et al., 2008). 
Tabel 2. Uji Penapisan Kemampuan Produksi Indole dan Pelarut Fosfat (P) dari isolat bakteri rizosfir bayam

\begin{tabular}{|c|c|c|c|}
\hline Nama Is olat & $\begin{array}{c}\text { Produksi Senyawa } \\
\text { Indole }\end{array}$ & $\begin{array}{c}\text { Kemapuan } \\
\text { melarutkan } P(\%)\end{array}$ & Asal Isolat \\
\hline 1BH4 & +++ & 60 & Sentagi 1 \\
\hline 1BH5 & +++ & $\mathrm{O}$ & Rangkang \\
\hline 1BH1 & ++ & $\mathrm{O}$ & Sentagi 2 \\
\hline 2BM 1 & ++ & $\mathrm{O}$ & Sebopet \\
\hline 3BH1 & + & $\mathrm{O}$ & Sentagi 2 \\
\hline 4BM 1 & + & $\mathrm{O}$ & Sebopet \\
\hline 5BM 1 & ++ & 33 & Sebopet \\
\hline 6ВH3 & ++ & $\mathrm{O}$ & Tampe \\
\hline 7ВH3 & +++ & $\mathrm{O}$ & Tampe \\
\hline 8BH3 & +++ & $\mathrm{O}$ & Tampe \\
\hline 9ВH3 & ++ & $\mathrm{O}$ & Tampe \\
\hline 1ОВН3 & + & $\mathrm{O}$ & Tampe \\
\hline 11BH5 & ++ & $\mathrm{O}$ & Rangkang \\
\hline $12 \mathrm{BH} 3$ & ++++ & 63,63 & Tampe \\
\hline 13BH4 & +++ & 80 & Sentagi 1 \\
\hline 14BH4 & ++ & $\mathrm{O}$ & Sentagi 1 \\
\hline
\end{tabular}

Keterangan : + untuk menggambarkan tingkat kepekatan warna merah yang identik dengan kandungan senyawa indol di media kultur.

Tabel 3. Rerata variabel kecambah bayam setelah direndam dalam suspensi bakteri selama 12 jam.

\begin{tabular}{lccccc}
\hline Isolat bakteri & $\begin{array}{c}\text { Kecepatan } \\
\text { tumbuh (hari) }\end{array}$ & Vigor (\%) & $\begin{array}{c}\text { Kecambah } \\
\text { normal }(\%)\end{array}$ & $\begin{array}{c}\text { Panjang } \\
\text { akar }(\mathrm{cm})\end{array}$ & Tinggi kecambah $(\mathrm{cm})$ \\
\hline Kontrol & $3,17 \mathrm{a}$ & $63,20 \mathrm{~b}$ & $71,20 \mathrm{c}$ & $1,61 \mathrm{a}$ & $2,21 \mathrm{ab}$ \\
$12 \mathrm{BH} 3$ & $3,07 \mathrm{a}$ & $68,80 \mathrm{~b}$ & $79,20 \mathrm{~b}$ & $1,66 \mathrm{a}$ & $1,95 \mathrm{~b}$ \\
$13 \mathrm{BH} 4$ & $3,17 \mathrm{a}$ & $82,80 \mathrm{a}$ & $98,40 \mathrm{a}$ & $1,86 \mathrm{a}$ & $2,51 \mathrm{a}$ \\
Komersial & $3,19 \mathrm{a}$ & $70,40 \mathrm{~b}$ & $78,40 \mathrm{~b}$ & $1,54 \mathrm{a}$ & $2,38 \mathrm{a}$ \\
\hline
\end{tabular}

Keterangan: angka yang diikuti huruf yang sama pada kolom yang sama tidak berbeda berdasarkan uji Tukey $\alpha=0,05$

Perlakuan kontrol benih direndam dalam larutan TSB

Isolat 13BH4 sebagai bakteri yang mampu menambat $\mathrm{N}$ menyebabkan kecambah normal, panjang akar dan tinggi tanaman yang tertinggi dibandingkan isolat lainnya (tabel 3). Hasil isolasi bakteri penambat $\mathrm{N}$ meliputi beberapa spesies Azotobacter yang dilakukan oleh Rubio et al. (2013) ternyata tidak semua sama baik dalam menghasilkankan IAA serta hormon lain seperti GA3 yang berperan dalam mempengaruhi pembentukan akar cabang pada gandum. Semakin tinggi IAA yang dihasilkan maka akar cabang juga meningkat. Meningginya konsentrasi IAA di perakaran juga berkaitan dengan meningkatnya sel bakteri yang menghuni permukaan akar. Senyawa IAA yang dihasilkan oleh $A$. chrococcum tidak saja berpengaruh terhadap perkembangan akar tetapi juga terhadap pertumbuhan tanaman timun (Salhia, 2010). Pada benih bayam, A. retroflexus yang dorman akibat lama disimpan ternyata dapat meningkat perkecambahannnya karena pengaruh pemberian etafon yang dapat melepaskan GA3 dan etilen (Pczynski dan Sznigir, 2012)

A. chroocuccum tidak saja mampu menghasilkan IAA tetapi juga hormon tumbuh lainnya seperti 3 jenis senyawa yang mirip GA3 (Brown and Burlingham, 1968) 
sehingga dapat meningkatkan berat akar dan pucuk dari stek tebu di media kultur jaringan (Mirza et al., 2001).

Hasil pengujian kemampuan bakteri dalam memacu perkecambahan benih bayam hijau tidak sama. Persentase perkecambahan normal yang memberikan hasil terbaik adalah isolat isolat $13 \mathrm{BH} 4$ dengan persentase kecambah normal mencapai 98,40 \%. Tinggi perkecambahan isolat yang memberikan hasil terbaik adalah isolat komersial dengan tinggi perkecambahan 2,38 cm tetapi tidak berbeda dengan isolat lokal 13 BH4 dan kontrol. Tidak adanya pengaruh bakteri penambat $\mathrm{N}$ terhadap tinggi kecambah mungkin terjadi karena terbatasnya faktor ketersediaan hara yang digunakan untuk pertumbuhan tanaman selama proses perkecambahan yang dilakukan pada media kertas. Bakteri hanya menghasilkan senyawa fitohormon yang akan direspon tanaman berupa pertumbuhan jika faktor yang diperlukan untuk tumbuh tersedia. Bakteri penambat $\mathrm{N}$ ternyata dapat meningkatkan kecambah normal sehingga baik digunakan untuk meningkatkan kemampuan benih bayam dalam perkecambahan. Perbedaan antara perkecambahan yang tergolong normal dan tidak normal bisa diamati pada gambar 4 .

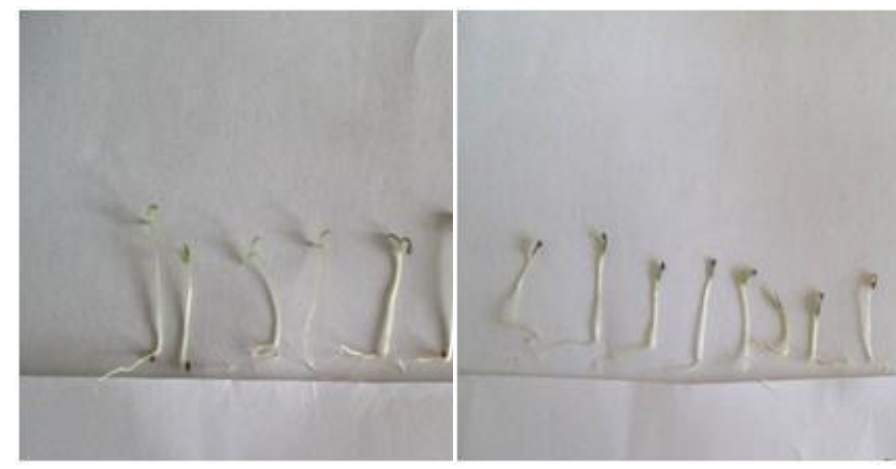

Gambar 4. Perkecambahan a. Tumbuh normal, b. Tumbuh tidak normal

\section{KESIMPULAN DAN SARAN}

\section{Kesimpulan}

Pada rizosfer bayam liar diperoleh 16 isolat bakteri yang mempunyai kemampuan menambat N. Setelah dilakukan karakterisasi terhadap kemampuan melarutkan $\mathrm{P}$ yang terikat $\mathrm{Ca}$ dan produksi senyawa indole didapatkan 2 isolat yang dapat digolongkan unggul, yaitu $12 \mathrm{BH} 3$ dan $13 \mathrm{BH} 4$.

Isolat bakteri penambat $\mathrm{N}$ yang mirip dengan Azotobacter sp. hanya dapat meningkatkan perkecambahan benih dan tinggi kecambah bayam hijau tetapi tidak terhadap panjang akar dan kecepatan tumbuh.

Saran

Isolat lokal bakteri penambat $\mathrm{N}$ yang berhasil diisolasi berpotensi dikembangkan secara komersial dalam pengembangan bayam di lahan marjinal. Untuk itu perlu pengujian lanjutan tentang stabilitasnya dalam membantu pertumbuhan tanaman.

\section{DAFTAR PUSTAKA}

Aryanto A, Triadiati, Sugiyanta. 2015. Pertumbuhan dan produksi padi sawah dan gogo dengan pemberian pupuk hayati berbasis bakteri pemacu tumbuh di tanah masam. J Ilmu Pertanian Indonesia 20(3): 229-235.

Brown ME and SK Burlingham. 1968. Production of plant growth substances by Azotobacter chroococcum. J Gem Microbial. 53:135-144

Edi S dan J Bobihoe. 2010. Budidaya Tanaman Sayuran. BPTP Jambi Balai Besar Pengkajian dan Pengembangan Teknologi Pertanian Kementan RI.

Rubio EJ, MS Montecchia, M Tosi, FD Cassán, A Perticari, OS Correa. 2013. Genotypic characterization of Azotobacteria isolated from Argentinean soils and plant-growth-Promoting traits of selected strains with prospects for biofertilizer production. Scien World J. 12p

Hastuti RD. 2012. Bakteri penambat nitrogen hidup bebas, p. 23-30. Dalam Saraswati R, Husin E, Simanungkalit RDM (editor). Metode Analisis Biologi Tanah. BB Litbang SDL Departemen Pertanian. Jakarta.

Jiménez DJ, JS Montaña, MM Martínez. 2011. Characterization of free nitrogen fixing bacteria of genus Azotobacter in organic vegetable-grown Colombian soils. Braz J Microb 42: 846-858

Kepczynski J and P Sznigir. 2012. Response of Amaranthus retroflexus L. seeds to gibberellic acid, ethylene and abscisic acid depending on duration of stratification and burial. Plant Growth Regul 70:1526

Kholida FT dan E Zulaika. 2015. Potensi Azotobacter sebagai penghasil hormon IAA (Indole-3-AceticAcid). J Sains Seni ITS. 4(2): 2337-3520.

Kurdish IK, ZT Bega, AS Gordienko, DI Dyrenko. 2008. The effect of Azotobacter vinelandii on plant seed germination and adhesion of these bacteria to cucumber roots. Applied Biochem Microbiol 45(4): 400-404

Mirza MS, W Ahmad, F Latif, J Haurat, R Bally, P Normand, KA Malik. 2001. Isolation, partial characterization, and the effect of plant growthpromoting bacteria (PGPB) on micro-propagated sugarcane in vitro. Plant Soil 237: 47-54

Nawangsih AA. 2007. Pemanfaatan bakteri endofit pada pisang untuk mengendalikan penyakit darah: 
Isolasi, uji penghambatan in vitro dan in planta. $\mathbf{J}$ llmu Pertanian Indonesia 12(1): 43-49.

Naz I, A Bano, B Rehman, S Pervaiz, M Iqbal, A Sarwar, F Yasmin. 2012. Potential of Azotobacter vinelandii Khsr as bioinoculant. African J Biotech 11(45):10368-10372

Nurmas A, Nofianti, A Rahman, A Khaeruni. 2014. Eksplorasi dan karakterisasi Azotobacter indigenus untuk pengembangan pupuk hayati tanaman padi gogo lokal di lahan marjinal. J. Agroteknos 4(2): $127-133$

Rachmawati D dan E Korlina. 2016. Kajian penggunaan pupuk hayati untuk mengendalikan penyakit akar gada (Plasmodium brassicae) pada sawi daging. Agrivor 9(1): 67-72

Rey P, S Leucart, H Desilets, RR Belanger, JP Larue, Y Tirilly. 2001. Production of indole-3-acetic acid and tryptophol by Pythium ultimum and Pythium group F: Possible role in pathogenesis. European J Plant Pathology 107: 895-904

Rubio EJ, MS Montecchia, M Tosi, FD Cassán, A Perticari, OS Correa. 2013. Genotypic characterization of Azotobacteria isolated from Argentinean soils and plant-growth-promoting traits of selected strains with prospects for biofertilizer production. Scie. World J 1: 1-12.
Rukmana, R. 1994. Bertanam Bayam dan Pengolahan Pasca Panen Yogyakarta Kanisius

Salhia BM. 2010. The Effect of Azotobacter chrococcum as nitrogen biofertilizer on the growth and yield of Cucumis sativus. Thesis for master degree. Faculty of Science of Biological Sciences The Islamic University - Gaza.

Santosa E. 2012. Bakteri pelarut fosfat, p. 55-68. Dalam Saraswati R, Husin E, Simanungkalit RDM (editor). Metode Analisis Biologi Tanah. BB Litbang SDL Departemen Pertanian. Jakarta.

Sunarjono, H. 2006. Bertanam 30 Jenis Sayur. Penebar Swadaya. Jakarta

Suwarno FC dan I Hapsari. 2008. Studi alternatif substrat kertas untuk pengujian viabilitas benih dengan metode uji UKDdp. Bul. Agron. 36(1): 84-91.

Wani SA, S Chand, T Ali. 2013. Potential Use of Azotobacter chroococcum in Crop Production: An Overview. Curr. Agri. Res. 1(1): 35-38

Zinniel DK, PA Lambrecht, NB Harris, Z Feng, D Kuczumarski, O Higley, CA Ishimaru, A Arunakumari, RG Barletta, and AK Vidaver. 2002. Isolation and characterization of endophytic colonizing bacteria from agronomic crops and prairie plants. American Society Microbiol 68(5): 2198-2208. 